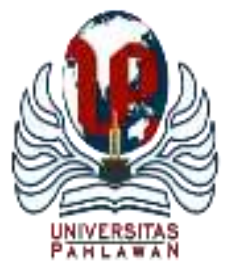

Edukatif : Jurnal Ilmu Pendidikan Volume 4 Nomor 1 Tahun 2022 Halm 1150 - 1156 EDUKATIF: JURNAL ILMU PENDIDIKAN

Research \& Learning in Education

https://edukatif.org/index.php/edukatif/index

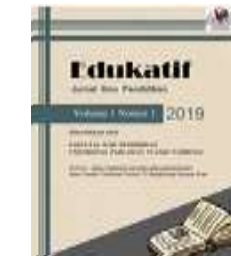

\title{
Peningkatan Kualitas Proses dan Prestasi Belajar Siswa SMK Teknik Otomotif dengan Blended Learning di Masa Pandemi Covid-19
}

\author{
Susi Tri Umaroh ${ }^{1 凶}$, Soeryanto $^{2}$, Warju $^{3}$, Supari Muslim ${ }^{4}$ \\ Universitas Negeri Surabaya, Indonesia ${ }^{1,2,3,4}$ \\ E-mail : susitriumaroh1997@gmail.com ${ }^{1}$, soeryanto@unesa.ac.id ${ }^{2}, \underline{w a r j u} @ u n e s a . a c . i d^{3}, \underline{\text { supari@unesa.ac.id }}^{4}$
}

\begin{abstract}
Abstrak
Pandemi Covid-19 yang terjadi menimbulkan berbagai dampak disemua sektor, salah satunya pada sektor pendidikan. Pembelajaran yang semula tatap muka harus berganti dengan pembelajaran jarak jauh untuk mengurangi penyebaran virus. SMK merupakan sekolah yang lulusannya diharapkan mampu memiliki kompetensi untuk siap kerja oleh karena itu pembelajaran yang diberikan meliputi teori dan praktik yang mana lebih besar prosentase praktiknya. Untuk mengatasi hal itu, sebagai upaya untuk tetap meningkatkan kualitas proses dan prestasi belajar siswa maka dibutuhkan kombinasi pembelajaran dengan blended learning (online dan tatap muka). Tujuan dari artikel ini yaitu mengkaji penerapan blended learning SMK Teknik Otomotif pada massa pandemi. Metode yang digunakan dari artikel ini adalah literature review. Literature review dilakukan dari beberapa macam sumber seperti jurnal nasional maupun internasional seperti dengan menggunakan database Google Schoolar, Science Direct, Springer, DOAJ, Scopus dll dan textbook atau handbook yang bersangkutan mengenai hasil penelitian blended learning di SMK Otomotif. Hasil yang diperoleh dari kajian literatur ini adalah pembelajaran blended learning dengan menggunakan media video tutorial berbasis Youtube di masa pandemi covid-19 efektif untuk meningkatkan kualitas proses dan prestasi belajar siswa SMK Teknik Otomotif.
\end{abstract}

Kata Kunci: blended learning, kualitas proses, prestasi belajar.

\begin{abstract}
The Covid-19 pandemic that has occurred has had various impacts in all sectors, one of which is the education sector. Learning that was originally face-to-face must be replace by distance learning to reduce the spread of the virus. Vocational High School is a school whose graduates are expect to be able to have the competence to be ready to work therefore the learning provided includes theory and practice where the percentage of practice is greater. To overcome this, as an effort to continue to improve the quality of the process and student achievement, a combination of learning with blended learning (online and face-to-face) is need. The purpose of this article is to examine the application of blended learning at the Automotive Engineering Vocational School in the pandemic mass. The method used in this article is a literature review. Literature review carried out from several sources such as national and international journals such as using the Google Scholar, Science Direct, Springer, DOAJ, Scopus etc. and the relevant textbook or handbook regarding the results of blended learning research at the Automotive Vocational School. The results obtained from the literature review this is a blended learning using YouTube-based video tutorial media during the covid-19 pandemic, which is effective for improving the quality of the process and learning achievement of Automotive Engineering Vocational High School students.
\end{abstract}

Keywords: blended learning, quality of learning process, learning achievement.

Copyright (c) 2022 Susi Tri Umaroh, Soeryanto, Warju, Supari Muslim

$\triangle$ Corresponding author

Email : susitriumaroh1997@gmail.com

DOI : https://doi.org/10.31004/edukatif.v4i1.2068

ISSN 2656-8063 (Media Cetak)

ISSN 2656-8071 (Media Online)

Edukatif : Jurnal Ilmu Pendidikan Vol 4 No 1 Tahun 2022 p-ISSN 2656-8063 e-ISSN 2656-8071 
1151 Peningkatan Kualitas Proses dan Prestasi Belajar Siswa SMK Teknik Otomotif dengan Blended Learning di Masa Pandemi Covid-19- Susi Tri Umaroh, Soeryanto, Warju, Supari Muslim

DOI: https://doi.org/10.31004/edukatif.v4i1.2068

\section{PENDAHULUAN}

Pada akhir tahun 2019, dunia digemparkan dengan adanya wabah pandemi virus corona (Covid-19) yang pertama terjadi di negara China. Indonesia termasuk negara yang juga terkena wabah pandemi Covid-19 pada awal tahun 2020. Tentu saja wabah ini menimbulkan berbagai kebijakan dari pemerintah untuk mengurangi penularan virus Covid-19. Kebijakan yang dilurncurkan oleh pemerintah antara lain menerapkan Pembatasan Sosial Berskala Besar (PSBB), anjuran protokol kesehatan, lockdown dibeberapa wilayah, work from home (WFH), dsb. Tentu saja aturan ini diberlakukan pada semua bidang salah satunya yaitu bidang pendidikan. Kegiatan pendidikan baik formal maupun non formal, baik tingkat prasekolah sampai pendidikan tinggi negeri maupun swasta. Keadaan ini menimbulkan aktivitas belajar mengajar menjadi terhambat. Namun tidak dapat dipungkiri bahwa pendidikan harus tetap berjalan sehingga kebijakan Menteri Pendidikan menetapkan untuk kegiatan belajar dari rumah. Kebijakan belajar di rumah dilaksanakan dengan tetap melibatkan pendidik dan peserta didik melalui Pembelajaran Jarak Jauh (PJJ) (Arifa, 2020). Sehingga pembelajaran jarak jauh menjadi solusi untuk mengatasi kesulitan dalam melaksanakan pembelajaran secara tatap muka langsung, dimana mengharuskan pembelajaran dilakukan secara online (Hardini et al., 2021). Ini memberikan tantangan kepada semua elemen dan jenjang pendidikan untuk mempertahankan kelas tetap aktif meskipun sekolah telah ditutup (Herliandry \& Suban, 2020). Namun, karena kondisi pandemi yang tidak memperbolehkan melakukan pembelajaran secara tatap muka maka berbagai upaya dilakukan oleh pendidik untuk tetap memberikan pembelajaran kepada siswa pada masa pandemi ini salah satunya dengan menggunakan media online, media maupun platform digital, serta media sosial untuk menunjang pembelajaran tersebut. Aplikasi-aplikasi belajar online dikembangkan dengan penyediaan fitur-fitur yang memudahkan kegiatan belajar, seperti Whatsapp Group, Google Classroom, YouTube, Ebook dan Powerpoint (Barlian, 2021).

Namun, seiring dengan kondisi serta masukan dari berbagai pelaku pendidikan, sehingga terdapat kebijakan baru menanggapi hal tersebut. Pendidikan menengah kejuruan (SMK) merupakan salah satu dari penyelenggaraan pendidikan yang bertujuan untuk mempersiapkan peserta didik, terutama untuk bekerja pada bidang ketrampilannya masing-masing (Sudarsono, 2020), sehingga pertimbangan proses pembelajaran di SMK harus benar-benar mendapat perhatian lebih terutama di masa pandemi. Oleh sebab itu, pihak Kementrian Pendidikan memberikan kebijakan baru terkait hal tersebut. Berdasarkan pernyataan Kemendikbud bahwa, "pembelajaran praktik adalah keahlian inti SMK, pelaksanaan pembelajaran praktik mata pelajaran produktif bagi peserta didik SMK diperbolehkan di semua zona dengan wajib menerapkan protokol kesehatan" (Kemendikbud, 2020). Oleh karena itu, pembelajaran tatap muka diperkenankan untuk siswa SMK namun tidak secara keseluruhan, dalam artian secara bergilir dengan tetap menjaga protokol kesehatan yang ketat. Disamping itu, kualitas proses pembelajaran juga merupakan hal yang tidak dapat dialihkan begitu saja.

Menurut Mariani, kualitas proses pembelajaran secara operasional dapat diartikan sebagai intensitas keterkaitan sistemik dan sinergis antara guru, siswa, iklim pembelajaran, serta media pembelajaran dalam menghasilkan proses dan hasil belajar yang optimal sesuai dengan tuntutan kurikuler (Haryati \& Rochman, 2012). Secara kasat mata indikator kualitas pembelajaran dapat dilihat antara lain dari perilaku pembelajaran guru (teacher behavior), perilaku dan dampak belajar siswa (student behavior), iklim pembelajaran (learning climate), materi pembelajaran, dan media pembelajaran (Haryati \& Rochman, 2012). Selain itu, dari sisi guru, kualitas dapat dilihat dari seberapa optimal guru mampu memfasilitasi proses belajar siswa, sedangkan dari sisi siswa, kualitas dapat dilihat perilaku dan dampak belajar siswa yang mampu membuat siswa termotivasi, aktif, dan kreatif, kemudian jika dilihat dari aspek iklim pembelajaran, kualitas dapat dilihat dari seberapa besar suasana belajar mendukung terciptanya kegiatan pembelajaran yang menarik, menantang, menyenangkan dan bermakna bagi siswa, Kemudian dari sisi media belajar kualitas dapat dilihat dari seberapa 
1152 Peningkatan Kualitas Proses dan Prestasi Belajar Siswa SMK Teknik Otomotif dengan Blended Learning di Masa Pandemi Covid-19- Susi Tri Umaroh, Soeryanto, Warju, Supari Muslim

DOI: https://doi.org/10.31004/edukatif.v4i1.2068

efektif media belajar digunakan oleh guru untuk meningkatkan intensitas belajar siswa, Sedangkan dari aspek materi, kualitas dapat dilihat dari kesesuaiannya dengan tujuan dan kompetensi yang harus dikuasai siswa (Haryati \& Rochman, 2012). Pembelajaran berkualitas adalah pembelajaran yang mampu meletakan posisi guru sehingga guru mampu memainkan peranannya dengan tepat sesuai kebutuhan (Noortsani, 2019). Oleh karena itu, kualitas proses pembelajaran dapat mengukur hasil capaian dari tujuan pembelajaran.

Menurut Gagne (Dahar, 1998) prestasi belajar berupa lima kecakapan manusia meliputi : 1) informasi verbal, 2) kecakapan intelektual , 3) diskriminasi, konsep konkret, konsep abstrak, aturan dan aturan yang lebih tinggi, 4) strategi kognitif, dan sikap, serta 5) kecakapan materiil. Prestasi belajar dalam dimensi pengembangan/pencapaian tujuan akhir adalah kepercayaan diri yang lebih besar, peningkatan partisipasi social, dan perbaikan hasil kerja dean pendapatan, peningkatan pemanfaatan layanan umum, peningkatan perhatian atas pendidikan anggota keluarga/masyarakat. Berdasarkan pendapat tersebut dapat disimpulkan bahwa prestasi belajar dirumuskan sebagai suatu aktivitas mental atau psikis, penguasaan pengetahuan dan ketrampilan ilmu pelajaran yang dimiliki oleh siswa. Jika suatu pembelajaran yang dilakukan secara tatap muka akan membuat siswa jauh lebih aktif dan termotivasi dalam belajar. Akan tetapi dengan kondisi lingkungan saat ini yang mengharuskan melakukan social distancing, maka diperlukan suatu gagasan baru agar pembelajaran tetap efektif dan efisien, maka blended learning dirasa cukup efektif untuk dapat diterapkan di era pandemi saat ini (Riinawati, 2021).

Oleh karena itu, untuk mendukung kualitas proses dan prestasi belajar siswa di masa pandemi covid-19 yang sesuai untuk pembelajaran teori maupun praktik mata pelajaran produktif siswa SMK banyak menggunakan Blended Learning dengan model pembelajaran yang sesuai. Pembelajaran kombinasi (blended learning) adalah sebuah metode pendidikan jarak jauh menjadi fokus utama yang didukung dengan pendidikan tradisional (tatap muka) (Abdelrahman \& Irby, 2016). blended learning adalah model pembelajaran yang mengintegrasikan inovasi dan kemajuan teknologi melalui sistem online learning dengan interaksi dan partisipasi dari model pembelajaran tradisional (Hendrayati \& Pamungkas, 2003). Pembelajaran kombinasi (blended learning) memiliki sejumlah keuntungan bagi siswa dan guru. Dimana pembelajaran ini memiliki dampak positif pada prestasi akademik siswa, kepuasan siswa, penggunaan sumber daya yang efisien, meningkatkan kemampuan komunikasi siswa (Ora et al., 2018). Selain itu, blended learning sangat mendukung pendidikan di era 4.0 (Hartono et al., 2018). Sebagai solusi dalam mengatasi permasalahan pembelajaran dimasa pandemi , blended learning merupakan pendekatan pembelajaran metodologis yang menghubungkan beberapa pendekatan berbasis Asyn-choronous Learning Network atau metode pembelajaran melalui pembelajaran internet (Kusdiyanti et al., 2020). Sehingga dalam penerapannya media pembelajaran online dalam Learning Management System (LMS) didesain ulang dengan memadukan sistem online dan tatap muka di kelas untuk menciptakan kegiatan pembelajaran yang mandiri, aktif, efektif dan efisien, pemanfaatan blended learning sebagai media pembelajaran kompetensi dasar vokasi dengan menggunakan Model blended learning memiliki efektivitas internal dan eksternal yang mampu meningkatkan keterampilan pemahaman atau pembelajaran teoritis bagi siswa (Kusdiyanti et al., 2020).

Pembelajaran yang memadukan antara online dan tatap muka merupakan salah satu jalan yang dirasa efektif pada saat ini. Siswa SMK jurusan Otomotif dimana pembelajaran yang prosentasenya lebih banyak praktik untuk dapat mencapai kompetensi yang diharapkan. Kebanyakan pembelajaran yang berbasis kompetensi sangat berpengaruh apabila menggunakan blended learning (Dwijonagoro \& Suparno, 2019). Oleh karena itu dimasa pandemi ini guru banyak memanfaatkan media seperti tutorial video, buku manual reparasi, e-learning, media sosial seperti Whatsapp, maupun media lainnya untuk mendukung pembelajaran di SMK Jurusan Otomotif. Namun, karena SMK jurusan Otomotif merupakan jurusan yang lebih banyak menangani secara langsung objek atau alat dan bahan kerja sehingga sangat cocok menggunakan video tutorial. Video tutorial merupakan media penyampai pesan yang bersifat fakta maupun fiktif, inforamatife, edukatif maupun instruksional (Apriansyah \& , Kusno Adi Sambowo, 2020). Salah satu situs media yang 
1153 Peningkatan Kualitas Proses dan Prestasi Belajar Siswa SMK Teknik Otomotif dengan Blended Learning di Masa Pandemi Covid-19- Susi Tri Umaroh, Soeryanto, Warju, Supari Muslim

DOI: https://doi.org/10.31004/edukatif.v4i1.2068

menyajikan video untuk menunjang pembelajaran adalah YouTube Channel (Irawan et al., 2020). YouTube adalah media sosial yang bertujuan untuk berbagi video dengan pengguna lain. Penggunaan YouTube bisa bertindak sebagai sumber belajar bagi siswa (Zufar et al., 2020). Banyak tutorial dan konten yang disajikan dalam YouTube. Seperti contohnya tutorial bermain alat musik, tutorial public speaking, kerajinan tangan, pengenalan kebudayaan daerah, dan masih banyak lagi. Video yang disajikan dalam YouTube memberikan kemudahan untuk langsung mempraktekan konten yang sedang ingin dipelajari (Luhsasi \& Sadjiarto, 2020). Selain itu media pembelajaran berbasis youtube dapat memberikan pengaruh baik terhadap hasil belajar siswa (Wulandari et al., 2021). Sehingga dengan adanya bantuan media pembelajaran berbasis video tutorial YouTube diharapkan mampu mendukung pembelajaran blended ditengah pandemi Covid-19 utamanya di jurusan otomotif. Tujuan dari artikel ini adalah mengkaji pembelajaran blended learning untuk meningkatkan kualitas proses dan hasil belajar siswa di SMK Jurusan Otomotif berbantuan video tutorial berbasis YouTube.

\section{METODE PENELITIAN}

Metode penelitian yang digunakan adalah metode literature review atau mengkaji literatur. Studi literatur (literature review) merupakan penelitian yang dilakukan oleh peneliti dengan mengumpulkan sejumlah buku buku, majalah, artikel, dll yang berkaitan dengan masalah dan tujuan penelitian (Barlian, 2021). Teknik ini dilakukan dengan tujuan untuk mengungkapkan berbagai teori-teori yang relevan dengan permasalahan yang sedang dihadapi/diteliti sebagai bahan rujukan dalam pembahasan hasil penelitian (Barlian, 2021). Literature review dilakukan bisa berasal dari beberapa macam sumber seperti jurnal nasional maupun internasional yang dilakukan seperti dengan menggunakan database Google Schoolar, Science Direct, Springer, DOAJ, Scopus dll dan textbook atau handbook yang bersangkutan mengenai hasil penelitian blended learning di SMK Otomotif.

\section{HASIL DAN PEMBAHASAN PENELITIAN}

Berdasarkan hasil studi literatur yang diperoleh hasil sebagai berikut:

Hasil penelitian (Hidayat \& Andira, 2019) penelitian menunjukkan pembelajaran dengan blended learning bahwa kelas eksperimen berada pada kategori tinggi dengan nilai rata-rata peserta didik adalah sebesar 86,17 sedangkan pada kelas kontrol berada pada kategori sedang dengan nilai rata-rata peserta didik adalah sebesar 78,06. sehingga dapat disimpulkan bahwa model pembelajaran blended learning berbantuan media schoology lebih efektif terhadap hasil belajar peserta didik kelas XI MIA MAN Pangkep dibandingkan model konvensional berbantuan powerpoint sehingga dapat meningkatkan kualitas proses dan prestasi belajar. (Pradhana et al., 2013) menyimpulkan, blended learning efektif jika diterapkan pada mata kuliah Body Otomotif sebagaimana ditunjukkan oleh indikator pembelajaran di kelas (pembelajaran klasikal), pembelajaran melalui e-learning, dan pembelajaran melalui field study yang keefektifannya tinggi. Keefektifan blended learning juga ditunjukkan melalui hasil belajar siswa dimana ketuntasan belajar 100\% dengan nilai rata-rata 81,59 .

Selain itu, penelitian (Iwantara et al., 2014), dengan adanya bantuan media YouTube menunjukkan bahwa media video YouTube lebih unggul dari media charta dalam menanamkan pemahaman konsep ke siswa. Penggunaan video YouTube terbukti efektif untuk membantu siswa dalam proses pembelajaran (Faizah et al., 2017) penggunaan channel YouTube efektif untuk memotivasi siswa agar lebih aktif di kelas (Muhammad Ilyas \& Putri, 2020). Begitu pula penelitian (Hong et al., 2020), bahwa YouTube dapat memberikan siswa pengetahuan yang baik, yang pada gilirannya dapat meningkatkan peluang mereka untuk terus belajar menari. Pada saat yang sama, hasil penelitian ini menunjukkan bahwa pembelajaran seni pertunjukan melalui media sosial seperti YouTube layak dilakukan. 
1154 Peningkatan Kualitas Proses dan Prestasi Belajar Siswa SMK Teknik Otomotif dengan Blended Learning di Masa Pandemi Covid-19-Susi Tri Umaroh, Soeryanto, Warju, Supari Muslim

DOI: https://doi.org/10.31004/edukatif.v4i1.2068

Berdasarkan penelitian Yunika, kelebihan video tutorial berbasis animasi ini, yaitu dapat mengurangi kejenuhan sebelum melaksanakan praktik, produk dilengkapi dengan narasi untuk menjelaskan langkahlangkah pelaksanaan Praktik Batu Beton, penggunaannya dapat mendukung pembelajaran mandiri menggunakan handphone ataupun komputer secara mudah sehingga cocok digunakan pada masa pandemi Covid-19, efektif digunakan, dan dapat meningkatkan hasil belajar (Yunika et al., 2020). Menurut Faizah, mahasiswa merasa lebih mudah belajar di rumah dengan akses YouTube. Mereka merasakan dampak adanya peningkatan kompetensi berbicara dakwah atau beretorika dakwah setelah mereka mengakses pembelajaran secara on line di rumah. Mereka lebih mendalami materi dan media setelah sampai di rumah (Faizah et al., 2017). Video dapat digunakan dalam pengajaran berbicara di mana siswa dapat melihat visual sambil mendengarkan pidato. YouTube mendorong sikap belajar yang positif jika dimasukkan ke dalam pengajaran di kelas untuk melengkapi pembelajaran bahasa khususnya berbicara (Muhammad Ilyas \& Putri, 2020).

Setelah mengaplikasikan saluran YouTube dalam pembelajaran, hasil penelitian menunjukkan peningkatan yang signifikan. YouTube meluncurkan desain baru untuk menyederhanakan antarmukanya dan meningkatkan waktu yang dihabiskan pengguna di situs. Ini memberi siswa koneksi visual, yang membantu guru untuk meningkatkan partisipasi siswa. Potensi kekuatan dan kegunaan teknologi bini baik di dalam kelas maupun ruang kelas online cukup menjanjikan, bila dikelola oleh instruktur yang terlibat yang cukup terampil dalam penerapannya (Burke et al., 2008).

Penelitian lain (Adisasongko, 2020) mengungkapkan bahwa dengan video tutorial mampu mengatasi permasalahan pembelajaran di masa pandemi di SMK Jurusan TKR sehingga siswa mampu menerima pembelajaran secara daring dan luring (blended learning) berbantuan video tutorial, apalagi siswa SMK sangat perlu adanya panduan terutama dalam hal praktikum, sehingga dengan adanya blended learning berbantuan video tutorial YouTube channel mampu meningkatkan kualitas proses dan prestasi belajar siswa SMK terutama jurusan teknik otomotif. Hal ini menunjukkan bahwa media YouTube channel dirasa efektif untuk menunjang pembelajaran blended dimasa pandemi Covid-19 bagi siswa SMK Teknik Otomotif yang membutuhkan panduan yang runtut dalam melakukan pekerjaan dibidangnya.

\section{Kelebihan dan Kekurangan Penerapan Blended Learning Berbantuan YouTube Channel}

Setiap media pembelajaran pasti memiliki kelebihan dan kekurangan dalam menunjang proses pembelajaran. Namun dengan blended learning berbantuan YouTube channel dirasa memiliki peran yang cukup signifikan dengan kelebihannya antara lain tersedianya berbagai tipe video yang beraneka ragam yang dapat membantu seorang Video Maker terinspirasi (Abdullah, 2018), lalu YouTube ini termasuk website yang sangat mudah untuk diakses melalui Komputer, Laptop, maupun Smartphone (Mahendra, 2020). Keunggulan lain YouTube dapat meningkatkan pemahaman konsep siswa mengenai materi yang dipelajari (Iwantara et al., 2014). Kemudian video tutorial dalam YouTube dapat diputar maupun di berhentikan sehingga dapat membantu dalam hal praktik maupun pemahaman konsep seperti materi pembelajaran otomotif bagi siswa SMK teknik otomotif. Namun terdapat kekurangan yang muncul ialah masih terdapatnya video yang tidak pantas dipertontonkan umum serta masih adanya ujaran kebencian yang sering terjadi di dalam kolom komentar (Faiqah, Nadjib and Amir, 2016).

\section{KESIMPULAN}

Dari hasil literature review yang diperoleh dapat disimpulkan bahwa penerapan blended learning pada pembelajaran dirasa dapat meningkatkan kualitas proses dan prestasi belajar siswa SMK Teknik Otomotif di masa pandemi dengan berbantuan video tutorial YouTube. Namun, ada beberapa hal yang perlu dipertimbangkan dalam rangka tetap menjaga motivasi dan semangat belajar siswa untuk menggunakan video tutorial berbasis YouTube. Oleh karena itu, pertimbangan dalam menjadikan konten YouTube sebagai sumber belajar adalah (1) mempersingkat durasi video dengan penjelasan yang singkat, ringkas, dan jelas karena 
1155 Peningkatan Kualitas Proses dan Prestasi Belajar Siswa SMK Teknik Otomotif dengan Blended Learning di Masa Pandemi Covid-19-Susi Tri Umaroh, Soeryanto, Warju, Supari Muslim

DOI: https://doi.org/10.31004/edukatif.v4i1.2068

video yang lebih pendek tidak akan membosankan bagi siswa dalam pelaksanaan proses pembelajaran, (2) pemberian isyarat atau penekanan pada setiap materi di YouTube karena siswa lebih mengutamakan kejelasan atau kesimpulan dari suatu materi yang diberikan dan (3) pengelolaan video pembelajaran yang berpusat pada satu channel YouTube (Zufar et al., 2020).

\section{UCAPAN TERIMA KASIH}

Penulis mengucapkan terimakasih kepada Prof. Dr. H. Supari Muslim, M.Pd., M.Pd., Dr. Soeryanto, M.Pd., dan Dr. Warju, S.Pd., S.T., M.T., yang telah memberikan arahan serta bimbingan dalam penyusunan artikel ini, semoga dapat bermanfaat dan semoga dapat memberikan semangat bagi kami untuk terus belajar dan memberikan kontribusi positif.

\section{DAFTAR PUSTAKA}

Abdelrahman, N., \& Irby, B. J. (2016). Hybrid Learning. International Journal Of Information Communication Technologies And Human Development, 8(1), 1-25. Https://Doi.Org/10.4018/Ijicthd.2016010101.

Abdullah, S. D. A. (2018) „Peran Hanan Attaki Dalam Membangun Persepsi Generasi Milenial Tentang Tuhan (Analisis Isi Atas Video "Kangen” Di Youtube)"e, Raushan Fikr, 7(1), Pp. 65-74.

Adisasongko, N. (2020). Pemanfaatan Media Video Tutorial Sebagai Alternatif Pembelajaran Di Masa Pandemi Pada Peserta Didik Kompetensi Keahlian Tkro Smk. 2019, 910-914.

Apriansyah, M. R., \& , Kusno Adi Sambowo, A. M. (2020). Pengembangan Media Pembelajaran Video Berbasis Animasi Mata Kuliah Ilmu Bahan Bangunan Di Program Studi Pendidikan Teknik Bangunan Fakultas Teknik Universitas Negeri Jakarta. Jurnal Pendidikan Teknik Sipil (Jpensil), 9(1), 8-18.

Arifa, F. N. (2020). Tantangan Pelaksanaan Kebijakan Belajar Dari Rumah Dalam Masa Darurat Covid-19. Xii(No.7/I/Puslit/April/2020), 13-18.

Barlian, I. Kudsi; D. P. M. S. I. U. (2021). Inovasi Pembelajaran Dengan Model Blended Learning Di Masa Pandemi Covid 19. Jurnal Inovasi Pendidikan Kejuruan, 1(1), 31-48.

Burke, S. C., Ph, D., Snyder, S. L., \& Ph, D. (2008). Youtube : An Innovative Learning Resource For College Health Education Courses An Overview Of Youtube Using Youtube In Higher Education. International Electronic Journal Of Health Education, 11, 39-46.

Dwijonagoro, S., \& Suparno, S. (2019). Pranatacara Learning: Modeling, Mind Mapping, E-Learning, Or Hybrid Learning? Cakrawala Pendidikan, 38(1), 156-173. Https://Doi.Org/10.21831/Cp.V38i1.23034.

Faizah, U., Fakhrudin, M., \& Purworejo, U. M. (2017). Implementasi Media Pembelajaran Youtube Retorika. Saga, 311-317.

Hamalik, Oemar. 2013. Kurikulum Dan Pembelajaran. Jakarta: Bumi Aksara.

Hardini, H. T., Taufiq M., Bahtiar, M. D., \& Pratiwi, V. (20216). The Use Of Online Learning Media And Learning Behavior As Predictors Of Student Accounting Understanding. Edukatif: Jurnal Ilmu Pendidikan, 3(6), 3663-3674.

Hartono, S., Kosala, R., Supangkat, S. H., \& Ranti, B. (2018). Smart Hybrid Learning Framework Based On Three-Layer Architecture To Bolster Up Education 4.0. Proceeding - 2018 International Conference On Ict For Smart Society: Innovation Toward Smart Society And Society 5.0, Iciss 2018, 2017, 1-5. Https://Doi.Org/10.1109/Ictss.2018.8550028.

Haryati, T., \& Rochman, N. (2012). Peningkatan Kualitas Pembelajaran Pendidikan Kewarganegaraan Melalui Praktik Belajar Kewarganegaraan (Project Citizen). Jurnal Ilmiah Civis, 2(2), 1-11. 
1156 Peningkatan Kualitas Proses dan Prestasi Belajar Siswa SMK Teknik Otomotif dengan Blended Learning di Masa Pandemi Covid-19- Susi Tri Umaroh, Soeryanto, Warju, Supari Muslim

DOI: https://doi.org/10.31004/edukatif.v4i1.2068

Http://Journal.Upgris.Ac.Id/Index.Php/Civis/Article/Viewfile/459/413.

Hendrayati, H., \& Pamungkas, B. (2003). Implementasi Model Hybrid Learning Pada Proses Pembelajaran Mata Kuliah Statistika Ii Di Prodi Manajemen Fpeb Upi Heny Hendrayati \& Budhi Pamungkas.

Herliandry, L. D., \& Suban, M. E. (2020). Pembelajaran Pada Masa Pandemi Covid-19. Jurnal Teknologi Pendidikan, 22(1), 65-70.

Hidayat, M. Y., \& Andira, A. (2019). Pengaruh Model Pembelajaran Hybrid Learning Berbantuan Media Schoology Terhadap Hasil Belajar Peserta Didik Kelas Xi Mia Man Pangkep. Jurnal Pendidikan Fisika, 7(2).

Hong, J., Chen, M., \& Ye, J. (2020). Acceptance Of Youtube Applied To Dance Learning. 10(1). Https://Doi.Org/10.18178/Ijiet.2020.10.1.1331.

Irawan, E., Ahmadi, Prianggono, A., Saputro, A., \& Rachmandhani, M. (2020). Youtube Channel Development On Education: Virtual Learning Solutions During The Covid-19 Pandemic. International Journal Of Advanced Science And Technology.

Iwantara, I. W., Sadia, I. W., \& Suma, I. K. (2014). Pengaruh Penggunaan Media Video Youtube Dalam Pemahaman Konsep Siswa. E-Journal Program Pascasarjana Universitas Pendidikan Ganesha.

Kusdiyanti, H., Zanky, M. N., \& Wati, A. P. (2020). Blended Learning For Augmented Reality To Increase Student Competitiveness The Filling Subject Toward Making Indonesia 4 . 0. 2020, 88-100. Https://Doi.Org/10.18502/Kss.V4i7.6845.

Luhsasi, D. Iga, \& Sadjiarto, A. (2020). Youtube: Trobosan Media Pembelajaran Ekonomi Bagi Mahasiswa. Jurnal Ekonomi Pendidikan Dan Kewirausahaan, 5(2), 219-229.

Mahendra, R. (2020). Youtube Sebagai Media Pembelajaran. May, 6-9.

Muhammad Ilyas, \& Putri, M. E. (2020). Youtube Channel: An Alternative Social Media To Enhance Efl Students' Speaking Skill. Journal Of English For Academic, 7(1), 77-87.

Noortsani, I. (2019). Meningkatkan Kualitas Proses Pembelajaran Melalui Penerapan Model Pembelajaran. l(1).

Ora, A., Sahatcija, R., \& Ferhataj, A. (2018). Learning Styles And The Hybrid Learning: An Empirical Study About The Impact Of Learning Styles On The Perception Of The Hybrid Learning. Mediterranean Journal Of Social Sciences, 9(1), 137-148. Https://Doi.Org/10.2478/Mjss-2018-0013.

Pradhana, R., Estriyanto, Y., \& Rohman, N. (2013). Efektivitas Penerapan Blended Learning (Classical Learning, E-Learning, Dan Field Study) Pada Mata Kuliah Body Otomotif Di Program Studi Ptm Jptk Fkip Uns Surakarta Tahun Akademik 2012/2013.

Riinawati. (2021). Hubungan Penggunaan Model Pembelajaran Blended Learning Terhadap Hasil Belajar Matematika Siswa Sekolah Dasar. Edukatif: Jurnal Ilmu Pendidikan, 3(6), 3794-3801.

Sudarsono, B. (2020). Pengembangan Media Pembelajaran Pengelasan Model Shielded Metal Arc Welding ( Smaw ) Bagi Siswa Smk The Development Of Shielded Metal Arc Welding ( Smaw ) Welding Learning Media For Vocational High Schools Students. 8(2), 17-24.

Wulandari, A. R., Masturi, M., \& Fakhriyah, F. (2021). Pengaruh Media Pembelajaran Berbasis Youtube Terhadap Hasil Belajar Ipa Siswa Di Sekolah Dasar. Edukatif: Jurnal Ilmu Pendidikan, 3(6), 3779_ 3785. Https://Edukatif.Org/Index.Php/Edukatif/Article/View/1251.

Yunika, E., Iriani, T., \& Saleh, R. (2020). Pengembangan Media Video Tutorial Berbasis Animasi Menggunakan 4d Untuk Mata Kuliah Praktik Batu Beton The Development Of Animation Based Video Tutorial. Snitt-Politeknik Negeri Balikpapan, 299-306.

Zufar, Z., Thaariq, A., Media, S., Resource, L., Normal, N., Sosial, M., Belajar, S., \& Normal, N. (2020). The Use Of Social Media As Learning Resources To Support The New Normal Zahid Zufar At Thaariq, 1. $18(02), 80-93$. 